\title{
Penelusuran Potensi Aktivitas Antibakteri dan Antioksidan Fraksi Kulit Pohon Faloak (Sterculia quadrifida R.Br)
}

\section{Discovery Potential Antibacterial and Antioxidant Activity of Faloak Bark Fraction (Sterculia quadrifida $\mathrm{R} . \mathrm{Br}$ )}

\author{
Rollando \\ Ro.llando@machung.ac.id \\ Program Studi Farmasi, Fakultas Sains dan Teknologi, Universitas Ma Chung \\ Malang, Jawa Timur
}

\begin{abstract}
Abstrak
Penduduk Nusa Tenggara Timur memanfaatkan kulit batang tumbuhan Faloak (Sterculia quadrifida R.Br.) sebagai tumbuhan obat untuk mengobati penyakit liver, gastroentritis, dan penambah stamina. Kulit batang Faloak mengandung senyawa fenol, flavonoid, dan terpenoid. Penelitian ini bertujuan menganalisis daya antibakteri dan antioksidan dari fraksi hasil pemisahan ekstrak etanol kulit Faloak. Fraksi 3 menunjukan aktivitas antibakteri yang tinggi (IC50) pada bakteri $B$. subtilis $(90.51 \mu \mathrm{g} / \mathrm{mL}$ ), E. coli $(80.12 \mu \mathrm{g} / \mathrm{mL})$, S.aureus $(77,87 \mu \mathrm{g} / \mathrm{mL})$, dan S.thypi $(61.23 \mu \mathrm{g} / \mathrm{mL}) . \quad \mathrm{Uji}$ aktivitas antioksidan menunjukan bahwa fraksi 2 mempunyai aktivitas antioksidan dan kandungan fenolik total yang paling tinggi $(34,16 \pm 0,76 \mathrm{mg}$ GAE).
\end{abstract}

Kata kunci: Kulit batang Faloak, aktivitas antibakteri, kandungan fenolat total, aktivitas antioksidan

\begin{abstract}
People on Timor island use Faloak (Sterculia quadrifida R.Br.) bark as herbal remedy to cure diseases such as liver diseases, gastroenteritis and as stamina booster. Faloak bark contains fenol, flavonoid, and terpenoid. This study aims to analyze the ability of antibacterial and antioxidant of fraction of faloak bark ethanol extract. Fraction 3 showed the highest antibacterial activity $\left(I C_{50}\right)$ to the bacteria B. subtilis $(90.51 \mu \mathrm{g} / \mathrm{mL})$, E. coli $(80.12$ $\mu \mathrm{g} / \mathrm{mL})$, S.aureus $(77,87 \mu \mathrm{g} / \mathrm{mL})$, and S.thypi $(61.23 \mu \mathrm{g} / \mathrm{mL})$. Antioxidant activity test showed that fraction 2 has highest phenol content $(34,16 \pm 0,76$ $m g$ GAE) and antioxidant activity.
\end{abstract}

Keywords: Faloak bark, fraction, antibacterial activiy, total phenolic, antioxidant activity.

\section{Pendahuluan}

Indonesia secara geografis beriklim tropis dengan curah hujan ratarata tinggi, terkenal memiliki beraneka ragam tumbuhan yang dapat dimanfaatkan untuk kepentingan manusia. Masyarakat Indonesia sejak zaman dahulu telah mengenal tumbuhan yang mempunyai khasiat obat atau menyembuhkan berbagai macam 
penyakit. Tanaman yang berkhasiat obat tersebut dikenal dengan sebutan tanaman obat tradisional (Thomas, 1993). Faloak (Sterculia quadrifida R.Br) secara empiris dikenal sebagai tanaman obat yang banyak digunakan oleh masyarakat didaerah Nusa Tenggara Timur. Masyarakat Timor menggunakan air rebusan bagian kulit dari batang tumbuhan faloak untuk menyembuhkan penyakit hepatitis, gastroentritis, diabetes dan rheumatoid arthritis (Siswandi et al, 2013).

Siwandi, et al (2013), melalui uji golongan senyawa kimia menyatakan bahwa ekstrak aseton, etil asetat, metanol, dan n-heksana dari kulit batang tumbuhan faloak memiliki senyawa flavonoid, fenolik dan terpenoid. Penelitian ini diharapkan dapat memperjelas dan memberikan informasi ilmiah tentang pengaruh ekstrak kulit batang faloak dengan melihat efek antioksidan dan efek antibakteri secara in vitro.

\section{Metode Penelitian}

Peralatan yang digunakan pada penelitian ini adalah vial, tabung ependorf, autoklaf (AC-300AE, Tiyoda Manufacturing Co. Ltd.), kotak aseptis, cawan petri, ose, plug, lampu Bunsen, shaking incubator, paper disc, microtiter plate 96-well, pinset, mikropipet, blue tip dan yellow tip, inkubator (Sakura, Jepang), oven, dan alat gelas (corong porselen, Erlenmeyer, chamber KLT, corong pisah, gelas ukur, pipet, dan cawan porselen), lemari es, neraca analitik (BP221S), Laminar Air Flow cabinet (FARRco), vortex (junke \& kunkel), spektrofotometer UVVIS, blender, corong, Buchner, oven, mikropipet 10-1000 $\mu \mathrm{L}$; 1-10 mL (Acura 825, Socorex), neraca analitik (Scaltec SBC 22, BP 160P), vacuum rotary evaporator (Junke \& Kunkel), waterbath (labo-tech, Heraceus), tabung reaksi bertutup, dan alat-alat gelas yang lazim digunakan di laboratorium analisis (Pyrex-Germany dan Iwaki).

Bahan

Bahan utama yang digunakan adalah kulit batang faloak, Muller Hinton, NA (Nutrient Agar), dan NB (Nutrient Broth). Mikroba uji berupa Escherichia coli,
Staphylococcus aureus, Bacillus subtilis, Salmonella thypi, dan kontrol positif berupa streptomisin. Lempeng silica gel $\mathrm{F}_{254}$ (E. Merck, Jerman), dan Silica gel $60 \mathrm{PF}_{254}$ untuk digunakan dalam KLT Preparatif. Pelarut ekstraksi (etanol), dan fase gerak untuk pemisahan dan pemurnian aquadest, metanol, n-heksana, kloroform dan etil asetat didapatkan dari E. Merck (Darmstat, Jerman). Hidrogen peroksida, buffer fosfat, potasium ferrisianida, $\mathrm{FeCl}_{3}$.

\section{Ekstraksi}

Kulit batang faloak sebanyak 3 $\mathrm{Kg}$ yang telah kering kemudian diserbuk, dilakukan maserasi selama 24 jam dengan menggunakan pelarut etanol $96 \%$ (perbandingan serbuk dan etanol 96\% (1:3)). Dilakukan pergantian pelarut etanol $96 \%$ sebanyak 3 kali. Filtrat diperoleh dengan cara disaring dengan corong Buchner. Seluruh filtrat yang diperoleh diuapkan penyarinya hingga kental dengan evaporator. Bobot ekstrak yang diperoleh adalah 100,7658 g dan rendemen yang diperoleh sebesar 3,35\%.

\section{Fraksinasi Ekstrak Etanol secara KLT Preparatif}

Fase gerak yang digunakan adalah kloroform: n-butanol: etil asetat dengan perbandingan $(3: 4: 1,5)$ dalam memisahkan senyawa aktif ekstrak etanol 96\%. Fase diam yang digunakan adalah silika gel 60 PF254 khusus preparatif. Selanjutnya dilakukan pemisahan senyawa aktif ekstrak etil asetat menggunakan KLT Preparatif. Kromatogram yang dihasilkan dideteksi dengan sinar tampak, sinar $\mathrm{UV}_{254}, \mathrm{UV}_{366}$,dan pereaksi semprot serium sulfat, kemudian ditandai. Bercak yang sudah ditandai masing-masing dikerok dan dikumpulkan, kemudian dilarutkan dengan larutan klorofom:metanol (1:1), disaring, dan dikeringkan.

\section{Skrining fraksi aktif}

Pengujian menggunakan aktivitas antimikroba dilakukan metode disc diffusion (Kirby-Bauer Test). Mikroba uji yang digunakan E.coli, S.aureus, B.subtilis, S.thypi. Dibuat seri konsentrasi fraksi uji 100; 50; 25; 12,5; dan 6,25 $\mu \mathrm{g} / \mu \mathrm{L}$. Sebanyak $10 \mu \mathrm{L}$ 
senyawa uji dengan lima konsentrasi tersebut diteteskan ke paper disc sehingga jumlah isolat pada setiap paper disc berturut-turut adalah 1000; 500; 250; 125; dan 62,5 $\mu \mathrm{g}$. Sebelum ditempelkan pada media berisi bakteri uji, paper disc yang berisi senyawa ditunggu sampai kering, yang menandakan pelarutnya sudah menguap. Digunakan kontrol positif 10 $\mu \mathrm{L}$ streptomisin $10 \mathrm{mg} / \mathrm{mL}$ dan kontrol pelarut $10 \mu \mathrm{L}$ etanol absolut steril (harus diuapkan). Kultur bakteri uji diinkubasi pada suhu 37 'C selama 18-24 jam, diamati zona hambatan di sekeliling paper disc, dan diperoleh fraksi aktif.

\section{Penentuan Inhibition concentration 50 $\left(I C_{50}\right)$ dan Kadar Bunuh Minimum (KBM) Fraksi (Penentuan Potensi Fraksi)}

KHM ditentukan dengan metode mikrodilusi. Ke dalam sumur microtiter plate 96-well dimasukkan $50 \mu \mathrm{L}$ media Muller Hinton, $50 \mu \mathrm{L}$ suspensi mikroba uji yang telah disesuaikan kekeruhannya dengan standar McFarland 0,5 dan diencerkan (1:10) dan $100 \mu \mathrm{L}$ fraksi aktif dengan seri konsentrasi 500; 250; 125; 62,5; 31,25; 15,63; 7,81; dan 3,91 $\mu \mathrm{g} / \mathrm{mL}$ sehingga konsentrasi akhir larutan adalah 250; 125; 62,$5 ; 31,25 ; 15,63 ; 7,81 ; 3,91$; dan 1,96 $\mu \mathrm{g} / \mathrm{mL}$. Sebagai kontrol fraksi, dimasukkan ke sumuran dengan mencampurkan $100 \mu \mathrm{L}$ fraksi setiap konsentrasi dan $100 \mu \mathrm{L}$ media tanpa bakteri, kontrol bakteri uji digunakan sebanyak $200 \mu \mathrm{L}$ bakteri uji, dan kontrol positif digunakan larutan streptomisin 10 $\mathrm{mg} / \mathrm{mL}$ sebanyak $100 \mu \mathrm{L}$ dan bakteri uji sebanyak $100 \mu \mathrm{L}$.

Pengamatan dilakukan setelah inkubasi pada suhu $37{ }^{\circ} \mathrm{C}$ selama $18-24$ jam. Densitas sel dihitung menggunakan instrumen microplate reader dengan pengukuran pada panjang gelombang UV pada 595 nm untuk mendapatkan absorbansi dari sel bakteri yang telah diberi perlakuan senyawa uji dan absorbansi sel bakteri yang tidak diberi perlakuan senyawa uji (kontrol). Nilai $\mathrm{IC}_{50}$ didapatkan dengan membuat grafik antara kadar isolat (absis) dengan persen penghambatan pertumbuhan bakteri (ordinat) dan dianalisis menggunakan metode Litchfield dan Wilcoxon (analisis probit).

Penentuan nilai KBM dilakukan dengan mengambil cairan dari tiap microtiter plate 96-well sebanyak $3 \mu \mathrm{L}$ lalu digoreskan pada media NA steril tanpa penambahan mikroba dan senyawa uji. Goresan pada media NA yang terlihat jernih setelah inkubasi (suhu $37{ }^{\circ} \mathrm{C}$ selama 18-24 jam) ditetapkan sebagai nilai KBM.

\section{Determinasi kandungan fenolat total fraksi}

Kandungan fenolat total dari tiap fraksi diestimasi menggunakan reagen Folin-Ciocalteu dengan standar asam galat. Setiap fraksi dilarutkan dalam metanol (2 $\mathrm{mg} / \mathrm{mL})$ dan ditambahakan dengan $500 \mu \mathrm{L}$ reagen Folin-Ciocalteu $(50 \%)$, kemudian ditambahkan dengan 2 $\mathrm{mL} \mathrm{Na} \mathrm{CO}_{3} 20 \%$. Volume akhir sebanyak $5 \mathrm{~mL}$ dengan ditambah aquadestilata. Campuran didiamkan pada temperatur ruangan selama 20 menit kemudian di tetapkan aborbansinya pada panjang gelombang $765 \mathrm{~nm}$. Prosedur yang sama juga dilakukan pada standar asam galat dengan konsentrasi 15, 30, 45, 60, 75 $\mu \mathrm{g} / \mathrm{mL}$ yang telah dilarutkan dalam metanol. Standar asam galat digunakan untuk membuat kurva standar kalibrasi. Diperoleh persamaan kurva baku total fenolik : $\mathrm{y}=0.0234 \mathrm{x}+2.332$ with $\mathrm{R}^{2}=$ 0.9998 .

\section{Uji aktivitas antioksidan dengan metode peroksida}

Kemampuan fraksi untuk menangkap hidrogen peroksida dilakukan berdasarkan metode Ruch et al,(1989). Larutan hidrogen peroksida (40 $\mathrm{mmol} / \mathrm{L})$ dibuat dengan mengunakan buffer fosfat (50 mmol/L, pH 7,5). Absorbansi hidrogen peroksida diukur pada panjang gelombang $230 \mathrm{~nm}$ menggunakan spektrofotometer. Fraksi dilarutkan dalam aquadestilata sehingga diperoleh konsentrasi $2 \mathrm{mg} / \mathrm{mL}$. Larutan kemudian ditambahkan hidrogen peroksida dan ditetapkan absorbansinya pada panjang gelombang $230 \mathrm{~nm}$ setelah 10 menit. Larutan kontrol dibuat dengan mencampur buffer fosfat tanpa penambahan hidrogen peroksida. 
Persentase kemampuan fraksi dalam menangkap hidrogen peroksida dihitung dengan menggunakan persamaan:

Penangkapan $\mathrm{H}_{2} \mathrm{O}_{2}(\%)=$

$$
\text { [(Ai -At) } / \text { Ai] } \times 100
$$

Ket.Ai:Absorbansi kontrol, At: Absorbansi sampel

\section{Uji aktivitas antioksidan dengan penurunan reduksi}

Potensi reduksi dari fraksi diukur menggunakan metode Oyaiju (1986). Setiap fraksi dan standar $(2 \mathrm{mg} / \mathrm{mL})$ dalam $1 \mathrm{~mL}$ aquadestilata dicampur dengan buffer fosfat $(2,5 \mathrm{~mL}, 0,2 \mathrm{~mol} / \mathrm{L}$, $\mathrm{pH} 6,6)$ dan potasium ferisianida $(2,5 \mathrm{~mL}$, $1 \% \mathrm{~b} / \mathrm{v})$. Setelah itu disetrifugasi selama 10 menit pada $3000 \mathrm{rpm}$. Ambil lapisan atas larutan $(2,5 \mathrm{~mL} 1 \% \mathrm{~b} / \mathrm{v})$, kemudian dicampur dengan aquadestilata $(2,5 \mathrm{~mL})$ dan $\mathrm{FeCl}_{3} \quad(0,5 \mathrm{~mL}, \quad 0,1 \% \mathrm{~b} / \mathrm{v})$. Absorbansi larutan diukur pada panjang gelombang $700 \mathrm{~nm}$ menggunakan spektrofotometer.

\section{Hasil dan Pembahasan}

Fraksinasi ekstrak etanol 96\% menggunakan metode kromatografi lapis tipis preparatif (KLTP), Kromatogram yang terdeteksi dibawah sinar UV254, UV366 dan deteksi dengan pereaksi serium sulfat kemudian dikelompokan menjadi 5 fraksi seperti yang terlihat pada Gambar 1.

Fraksi yang telah dikelompokan kemudian dipisahkan secara hati-hati dengan cara dikerok dan serbuk silika disimpan pada tempat yang khusus sesuai penggolongan fraksi. Serbuk silika dilarutkan dengan kloroform : metanol (1:1) kemudian disaring dengan milipore dan diuapkan hingga kering. Fraksi ditimbang sehingga diperoleh rendemen fraksi dengan cara membandingkan bobot fraksi terhadap ekstrak etil asetat seperti pada Tabel I. Fraksi yang diperoleh kemudian diuji aktivitasnya terhadap bakeri uji.

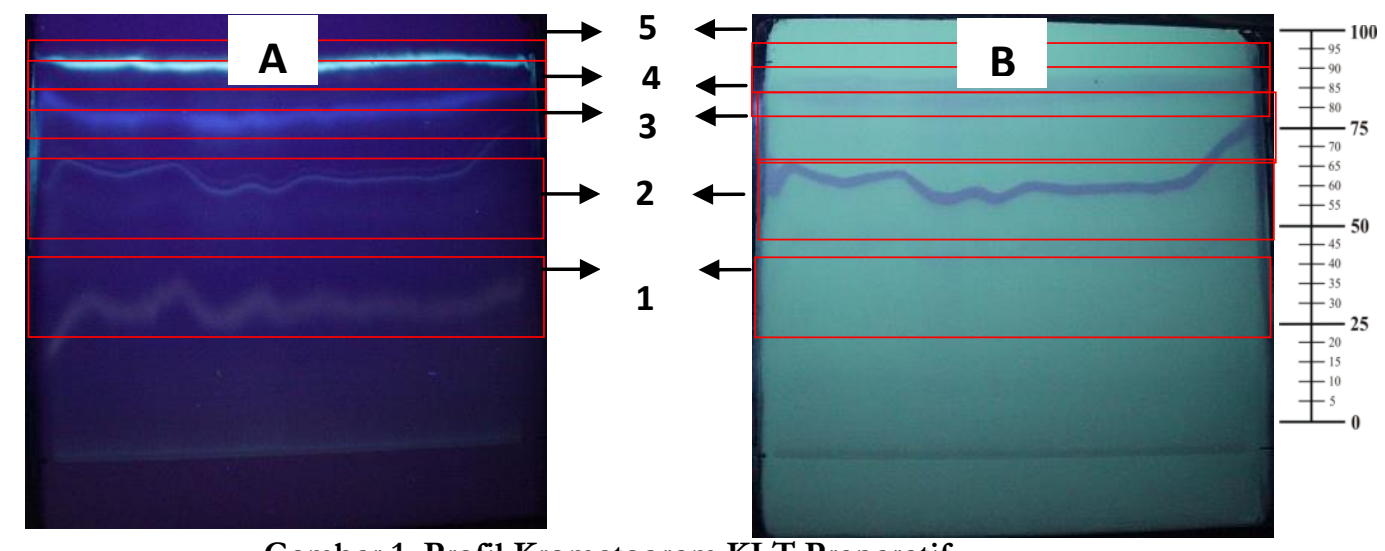

Gambar 1. Profil Kromatogram KLT Preparatif

Keterangan gambar: Fase diam silica gel 60 PF254 dan fase gerak kloroform : n-butanol : etil asetat (3:4:1,5). Visualisasi pemisahan fraksi secara KLT preparatif, yakni (A) kromatogram di bawah UV366, (B)

UV254 nm. (1) fraksi 1, (2) fraksi 2, (3)fraksi 3, (4) fraksi 4, dan (5) fraksi 5.

Tabel I. Rendemen dan hRf Fraksi

\begin{tabular}{cccccc}
\hline Fraksi & hRf & UV 254 & UV 366 & Serium Sulfat & $\begin{array}{c}\text { Rendemen } \mathbf{( \%} \\
\mathbf{b} / \mathbf{b})^{*}\end{array}$ \\
\hline $\mathbf{1}$ & 0 & Meredam & Berpendar biru & Coklat & 5,76 \\
$\mathbf{2}$ & 45 & - & Berpendar biru & Coklat & 15,60 \\
$\mathbf{3}$ & 74 & Meredam & Berpendar biru & Coklat & 20,57 \\
$\mathbf{4}$ & 80 & - & Berpendar biru & Coklat & 19,09 \\
$\mathbf{5}$ & 100 & Meredam & Berpendar hijau & Coklat & 10,53 \\
\hline
\end{tabular}

Keterangan: *Dihitung terhadap berat ekstrak etanol $96 \%=20,1123 \mathrm{~g}$ 


\section{Skrining Fraksi Aktif}

Berdasarkan tabel II menunjukan bahwa fraksi 1, 2, dan 3 mempunyai aktivitas yang lebih baik dalam menghambat pertumbuhan bakteri uji dari pada fraksi 4 dan 5. Fraksi 1 menghambat pertumbuhan bakteri S.aureus, B.subtilis, dan E.coli pada level konsentrasi tertinggi. Fraksi 2 mempunyai aktivitas menghambat pertumbuhan bakteri B.subtilis, E.coli, dan S.thypi tetapi tidak mempunyai aktivitas terhadap pertumbuhan bakteri S.aureus. Fraksi 3 mempunyai aktivitas terhadap bakteri S.aureus, B.subtilis, E.coli, dan S.thypi.

Berdasarkan keseluruhan aktivitas penghambatan pertumbuhan bakteri uji, fraksi 3 mempunyai aktivitas yang lebih besar daripada fraksi 1 dan fraksi 2 . Namun, bila dilihat dalam sudut pandang skrining aktivitas antibakteri, maka ketiga fraksi tersebut mempunyai potensi untuk dilakukan uji aktivitas (secara mikrodilusi).

Tabel II. Hasil Pengamatan Uji Disc Diffusion Fraksi terhadap Bakteri Uji

\begin{tabular}{|c|c|c|c|c|c|c|c|}
\hline \multirow[t]{2}{*}{ Fraksi } & \multirow[t]{2}{*}{$\begin{array}{c}\text { Loading } \\
(\mu \mathrm{g})\end{array}$} & \multicolumn{6}{|c|}{ Zona Hambatan Pertumbuhan (mm) } \\
\hline & & $\begin{array}{c}S . \\
\text { aureus }\end{array}$ & $\begin{array}{c}B . \\
\text { subtilis }\end{array}$ & E. coli & S. thypi & $\begin{array}{l}\text { Kontrol } \\
\text { Positif }\end{array}$ & $\begin{array}{l}\text { Kontrol } \\
\text { Negatif }\end{array}$ \\
\hline \multirow[t]{5}{*}{1} & 62,5 & ND & ND & ND & ND & 19 & \multirow{5}{*}{ ND } \\
\hline & 125 & ND & ND & ND & ND & & \\
\hline & 250 & ND & ND & 5 & ND & & \\
\hline & 500 & ND & 2 & 5 & ND & & \\
\hline & 1000 & 5 & 4 & 7 & ND & & \\
\hline \multirow[t]{5}{*}{2} & 62,5 & ND & ND & ND & ND & 18 & \multirow{5}{*}{ ND } \\
\hline & 125 & ND & ND & ND & ND & & \\
\hline & 250 & ND & 2 & ND & 5 & & \\
\hline & 500 & ND & 3 & 3 & 8 & & \\
\hline & 1000 & ND & 5 & 4 & 10 & & \\
\hline \multirow[t]{5}{*}{3} & 62,5 & 2 & ND & 2 & 4 & 20 & \multirow{5}{*}{ ND } \\
\hline & 125 & 2 & 3 & 2 & 6 & & \\
\hline & 250 & 4 & 6 & 2 & 5 & & \\
\hline & 500 & 5 & 7 & 3 & 9 & & \\
\hline & 1000 & 9 & 9 & 7 & 11 & & \\
\hline \multirow[t]{5}{*}{4} & 62,5 & ND & ND & ND & ND & 23 & \multirow{5}{*}{ ND } \\
\hline & 125 & ND & ND & ND & ND & & \\
\hline & 250 & ND & ND & ND & ND & & \\
\hline & 500 & ND & ND & ND & ND & & \\
\hline & 1000 & ND & ND & ND & ND & & \\
\hline \multirow[t]{5}{*}{5} & 62,5 & ND & ND & ND & ND & 17 & \multirow{5}{*}{ ND } \\
\hline & 125 & ND & ND & ND & ND & & \\
\hline & 250 & ND & ND & ND & ND & & \\
\hline & 500 & ND & ND & ND & ND & & \\
\hline & 1000 & 2 & ND & 3 & ND & & \\
\hline
\end{tabular}

Keterangan: ND $=$ not detected (tidak terdeteksi adanya aktivitas) 


\section{Uji fraksi aktif}

Tabel III menunjukan bahwa fraksi 3 lebih aktif daripada fraksi 1 dan fraksi 2 pada bakteri uji B. subtilis, E. coli, $S$. aureus, dan $S$. typhi. Hal tersebut ditunjukkan dengan menganalisis nilai $\mathrm{IC}_{50}$. Misalnya dalam menghambat pertumbuhan bakteri S.thypi, fraksi 3 memerlukan konsentrasi $77,87 \mu \mathrm{g} / \mathrm{mL}$ dalam menghambat $50 \%$ pertumbuhan bakteri daripada fraksi 2 yang memerlukan konsentrasi lebih tinggi yaitu 345,82 $\mu \mathrm{g} / \mathrm{mL}$.

Fraksi 3 mempunyai kemampuan membunuh bakteri atau nilai kadar bunuh minimum yang lebih aktif daripada fraksi 1 dan fraksi 2 terhadap bakteri B. subtilis, E. coli, S. aureus, dan S. typhi. Misalnya dalam membunuh bakteri E. coli, fraksi 3 dapat membunuh 99,9\% bakteri pada konsentrasi $500 \mu \mathrm{g} / \mathrm{mL}$ daripada fraksi 2, yaitu memerlukan dosis yang lebih tinggi dari $500 \mu \mathrm{g} / \mathrm{mL}$.

Tabel III. Nilai IC $_{50}$ dan Nilai KBM Fraksi

\begin{tabular}{ccccccc}
\hline BAKTERI & \multicolumn{9}{c}{ SENYAWA } \\
\cline { 2 - 7 } & \multicolumn{2}{c}{ Fraksi 1 } & \multicolumn{2}{c}{ Fraksi 2 } & \multicolumn{2}{c}{ Fraksi 3 } \\
& IC $_{50}$ & KBM & IC $_{50}$ & KBM & IC $_{50}$ & KBM \\
& $(\boldsymbol{\mu g} / \mathbf{m L}$ & $(\boldsymbol{\mu g} / \mathbf{m L})$ & $(\boldsymbol{\mu g} / \mathbf{m L})$ & $(\boldsymbol{\mu g} / \mathbf{m L})$ & $(\boldsymbol{\mu g} / \mathbf{m L})$ & $(\boldsymbol{\mu g} / \mathbf{m L})$ \\
B. subtilis & 123,76 & $>500$ & 125,87 & $>500$ & 90,51 & 500 \\
E. coli & 132,99 & $>500$ & 113,76 & $>500$ & 80,12 & 500 \\
S. aureus & 245,76 & $>500$ & 345,82 & $>500$ & 77,87 & 500 \\
S. typhi & 334,76 & $>500$ & 103,65 & 500 & 61,23 & 500 \\
\hline
\end{tabular}

\section{Analisis kandungan fenolik total}

Tabel IV menunjukan kandungan fenolik total dengan rentang yang cukup lebar. Nilai bervariasi dari 8,25 - 34,16 mg
GAE/g bobot kering fraksi. Kandungan tertinggi terdapat pada fraksi 2 (34,16 \pm 0,76 mg GAE) kemudian diikuti oleh fraksi 1 dan fraksi 3.

Tabel IV. Kandungan Fenolik Total Fraksi

\begin{tabular}{cc}
\hline Fraksi & Kandungan Fenolik Total (mg GAE/g Fraksi) \\
\hline $\mathbf{1}$ & $20,14 \pm 0,87$ \\
$\mathbf{2}$ & $34,16 \pm 0,76$ \\
$\mathbf{3}$ & $18,97 \pm 0,23$ \\
$\mathbf{4}$ & $8,25 \pm 0,16$ \\
$\mathbf{5}$ & $11,35 \pm 0,14$ \\
\hline
\end{tabular}

Uji aktivitas antioksidan dengan metode peroksida

Gambar 2 menunjukan bahwa aktivitas potensial penangkapan reduksi hidrogen peroksida dari fraksi menunjukan range aktivitas dari 23 -
87\%. Aktivitas reduksi dari vitamin C sebesar 93\%. Fraksi 2 menunjukan aktivitas paling besar dari semua fraksi, yaitu sebesar $87 \%$ kemudian diikuti oleh fraksi 1 sebesar $71 \%$. 


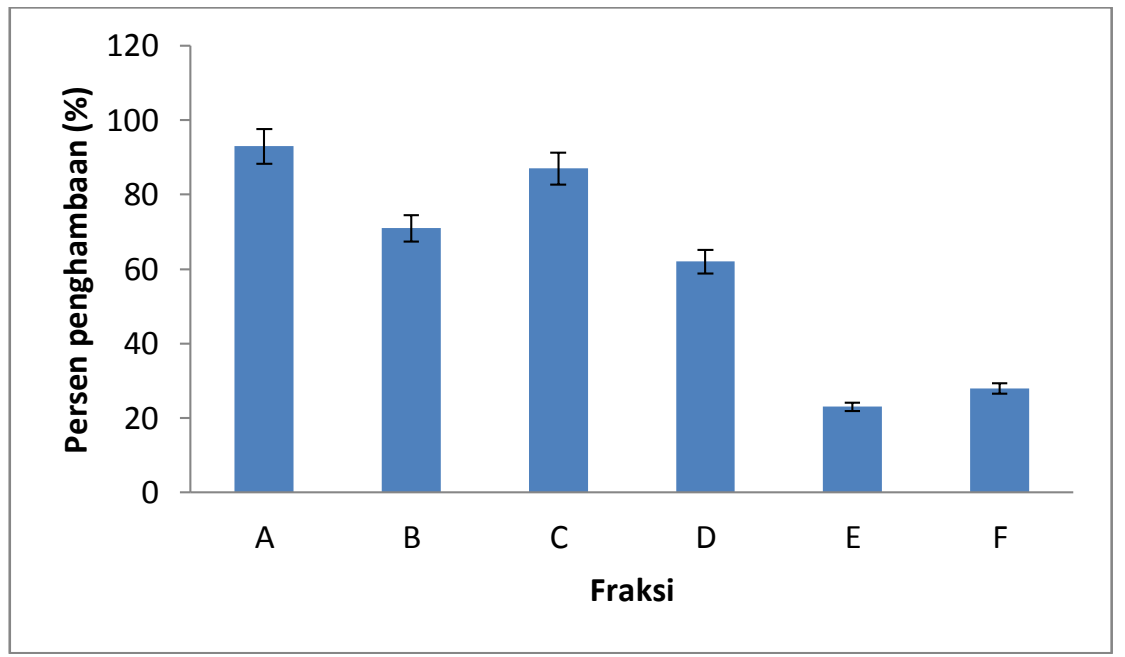

Gambar 2. Aktivitas Penangkapan Hidrogen Peroksida dari Fraksi dan Vitamin C

Keterangan gambar: A: Vitamin C, B: Fraksi 1, C: Fraksi 2, D: Fraksi 3, E: Fraksi 4, F: Fraksi 5

Uji aktivitas antioksidan dengan metode penurunan reduksi

Kemampuan reduksi pada metode penurunan reduksi diukur dari perubahan ion $\mathrm{Fe}^{3+}$ menjadi $\mathrm{Fe}^{2+}$. Fraksi 1 dan fraksi 2 menunjukan nilai absorbansi yang tinggi yang mengindikasikan potensi kemampuan yang besar dalam proses reduksi dan kemampuan mendonor elektron untuk menstabilkan radikal bebas. Gambar 3 menunjukan aktivitas reduksi dari vitamin C sebesar 95\% dan fraksi 2 mempunyai aktivitas penurunan reduksi terbesar yaitu $91 \%$.

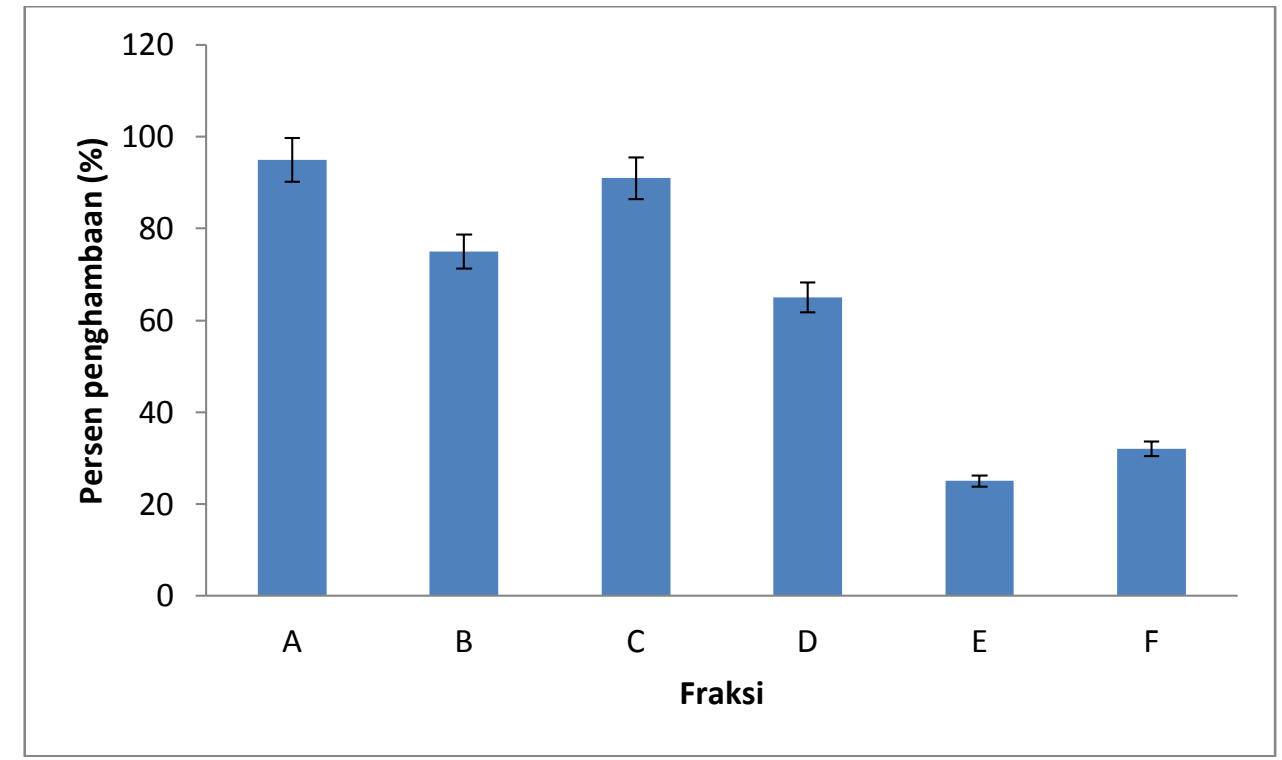

Gambar 3. Aktivitas Kemampuan Reduksi dari Fraksi dan Vitamin C

Keterangan gambar: A: Vitamin C, B: Fraksi 1, C: Fraksi 2, D: Fraksi 3, E: Fraksi 4, F: Fraksi 5

Hubungan kandungan fenolik total dengan aktivitas antioksidan

Uji aktivitas antioksidan menggunakan metode peroksida dan penurunan reduksi menunjukan hasil uji yang konsisten (Gambar 2 dan 3). Fraksi 2 mempunyai kandungan fenolik total terbesar dari semua fraksi $(34,16 \pm 0,76$ mg GAE). Fraksi 2 mempunyai aktivitas antioksidan terkuat dari semua fraksi, 
kemudian diikuti oleh fraksi 1 dan 3. Dari data tersebut menunjukan senyawa fenolik mempunyai peran dalam menurunkan aktifitas radikal bebas. Senyawa fenol mempunyai gugus hidroksi yang mempunyai peran utama dalam menangkap radikal bebas (Huang et al, 2005). Senyawa fenol dan terpen merupakan senyawa yang bertanggungjawab terhadap penurunan aktivitas peroksidasi lipid (Gulcin, 2006).

\section{Simpulan}

Uji aktivitas antibakteri menunjukan bahwa fraksi 3 mempunyai aktivitas paling tinggi terhadap bakteri uji B. subtilis, E. coli, S. aureus, dan S. typhi. Uji kandungan fenolik total menunjukan fraksi 2 mempunyai kandungan fenolik total terbesar dan mempunyai aktivitas antioksidan tertinggi.

\section{Ucapan Terimakasih}

Peneliti mengucapkan terima kasih kepada Siswandi, M. Hut yang telah memberikan batang faloak sebagai bahan uji yang digunakan dalam penelitian ini.

\section{Daftar Pustaka}

Gulcin I. Antioxidant and antiradical activities of L-carnitine. Life Sci 2006; 78(8): 803-811.
Huang,D., Ou,B., Proir,RL. The chemistry behind antioxidant capacity assays. J Agric Food Chem 2005; 53(6): 1841-1856.

Oyaizu,M. Studies on products of browning reaction: antioxidative activities of browning recation prepared from glucosamine. Jpn J Nutr 1986; 44(6): 307-315.

Ruch,RJ., Cheng,SJ., Klaunig, JE. Prevention of cytotoxicityand inhibition of intercellular communication by antioxidant catechins isolated from Chinese green tea. Carcinogenesis 1989; 10(6): 1003-1008.

Siswadi., Rianawati,H., Saragih,G., dan Hadi, D., The Potency of Faloak's (Sterculia quadrifida R.Br ) Active Compunds As Natural Remedy, Prosiding Seminar International, Kementrian Kehutanan bagian Penelitian dan Pengembangan Hutan, Bogor.

Thomas, 1993, Tanaman Obat Tradisional I, Penerbit Kanisius, Yogyakarta. 